\title{
PROCESS-GENRE APPROACH FOR TEACHING WRITING OF ENGLISH TEXT
}

\section{Dedi Jasrial}

\author{
English Study Program of Bengkulu University \\ dedijasrial92@gmail.com
}

Received on Feb, $21^{\text {st }}$, Revised on May, 20 ${ }^{\text {th }}$, Published on July, $30^{\text {st }} 2019$

\begin{abstract}
Although writing has been learned by students since they start to learn English language but it still become the most difficult skill to be acquired than speaking, reading and listening. It is possibility caused by the students have limitation of knowledge about writing roles, lack of vocabulary, lack of motivation, lack of master of language structure, and lack of ability in generating a topic. In addition, writing is also called as the most complexity skill and it can be seen from the process of writing, rules that must be followed by students, and the influence of non-linguistics factors during of writing activity. Therefore, students must be serious to acquire this skill. In this article, the writer would like to introduce a suitable approach to teaching writing of English texts through process-genre approach. After reading this article, the writer expects that this article can help English teachers to apply this approach for teaching writing of English texts at Junior and Senior High Schools in Indonesia.
\end{abstract}

Keywords: Process-genre approach, teaching writing, and English Texts.

\begin{abstract}
ABSTRAK
Walaupun menulis telah dipelajari oleh siswa sejak mereka mulai belajar bahasa Inggris tetapi itu masih menjadi keterampilan yang paling sulit diperoleh daripada berbicara, membaca dan mendengarkan. Kemungkinan itu disebabkan oleh siswa memiliki keterbatasan pengetahuan tentang peran menulis, kurangnya kosa kata, kurangnya motivasi, kurangnya struktur bahasa master, dan kurangnya kemampuan dalam menghasilkan topik. Selain itu, menulis juga disebut sebagai keterampilan yang paling rumit dan dapat dilihat dari proses penulisan, aturan yang harus diikuti oleh siswa, dan pengaruh faktor non-linguistik selama kegiatan menulis. Oleh karena itu, siswa harus serius untuk memperoleh keterampilan ini. Dalam artikel ini, penulis ingin memperkenalkan pendekatan yang cocok untuk pengajaran menulis teks bahasa Inggris melalui pendekatan genre proses. Setelah membaca artikel ini, penulis berharap bahwa artikel ini dapat membantu para guru bahasa Inggris untuk menerapkan pendekatan ini dalam pengajaran menulis teks-teks bahasa Inggris di SMP dan SMA di Indonesia.
\end{abstract}

Kata kunci: Pendekatan genre, pengajaran menulis, dan Teks Bahasa Inggris 


\section{INTRODUCTION}

Writing is a unique skill than other skills, and it must be acquired by students in learning English language. This skill is categorized as a productive skill (Khan, 2016) and it will be a cognitive challenge (Javed, Juan \& Nazli, 2013). Writing is also regarded as a process of communication in written form that informs information for readers (Purba, 2018). Therefore, achievements of learning writing are expected that students can share their ideas, arguments, opinion, or feeling to readers in a newspaper, a magazine, an article, and a book through writing.

Writing is the most important skill but it is considered as the most difficult skill of the four skills in learning English language. Sibarani (2007) argues that writing is difficult to be mastered because it is the most difficult of cognitive process. Hyland (2003) in Ahn (2012) argues that "difficulties in writing different types of text may come from the fact that writers have to understand the linguistics features of these different text types" (p. 2). Meanwhile, in writing students follow an ongoing process such as rewriting, revising, and editing their writing (Wang, 2015). Then, Richards and Renandya (2002) also claims that, translating ideas into readable text is also the difficulties of writing. Masood and Farooq (2013) also supported those statements in which they said that writing is a complex process. The complex process will make writing be not easy. It needs a practice to develop this skill. Those arguments can be inferred that writing is difficult because it has some continuity process of writing and process of translating. The aim of that process is to improve the quality of writing product of students. The qualified writing can make readers can understand and comprehend the information easily.

In academic field, especially, Junior High School and Senior High School students in Indonesia must learn some English text types. They are expected to have a good writing ability as an indicator of achievement in learning a foreign language. However, writing skill is difficult and it has been a big problem for some EFL students in learning writing. Kim and Kim (2005) stated that, this problem was faced by EFL students in Indonesia. The problem happened was caused by "writing session in the classroom consisted of very few acts of writing, saying that "practice of writing does take place in the class, yet it contributes almost nothing to the build-up of writing skills" (Alwasilah, 2001, p. 25 cited in Pujianto, Emilia \& Ihrom, 2014, p. 100). 
Besides, there are some other factors that cause the problem in mastering the writing skill. Karimnia (2013) states that, most students' attention to the process of writing was low and students have lack of ability to use appropriate words. The use of appropriate words can help the readers understanding meaning of a sentence well. Moreover, Tran (2007) in Tuyen, et. al, (2016) argues that the low level of students' motivation also influences EFL students in learning writing. Therefore, teachers must be able to use an effective and appropriate approach in teaching writing for EFL students in Indonesia.

The use of an approach for teaching writing is very important. It will influence on the successful of students in learning writing of English texts at school. Students need an effective approach in order the problems that were faced by them during learning writing skill can be solved. One of the potential approaches to solve those problems that have been explained above is by implementing process-genre approach (PGA). This approach is basically a synthesis of concept from both of the process-based approach and the genre-based approach (Badger \& White, 200; Kim \& Kim, 2005; Yan, 2005; Gao, 2007; Nordin \&
Muhammad, 2007; Babalola \& Litinin, 2012).

In addition, the process-genre approach has been done by some researchers from some countries in the world. The studies related to effects of process-genre approach are Foo (2007); Babola and Litinin (2012); Agesta and Cahyono (2017). Those studies revealed that process-genre approach gave a positive effect significantly on the students' writing achievement. Beside, some studies also implemented process-genre approach for teaching writing. For instances, Assagaf (2016); Saputra and Marzulina (2016); Tuyen (2016); Ghufron (2016); and Guspitasari (2013). All of these studies could improve students writing achievement in writing. Meanwhile, a case study has been conducted that focused on process-genre approach to teaching writing (Pujianto, Emilia \& Ihrom, 2014; Reonal, 2015) which revealed that students writing ability could improved by using processgenre approach.

Based on those study can be seen that the process-genre approach is very effective for teaching writing especially in teaching English texts. This approach is recommended for EFL teachers in Indonesia to teaching writing of English texts at Junior and Senior High Schools. This paper will 
discuss about learning English writing through process-genre approach that focuses on discussing the following questions, what is process-genre approach? What are the steps of process-genre approach? And Why is process-genre approach recommended to teaching writing of English texts?

\section{DISCUSSION}

\section{Process Genre Approach}

The term of process-genre approach was firstly introduced by Bedger and White (2000) in their article entitled a process genre approach to teaching writing. This approach is actually combination from process approach, product approach, and genre approach. Yan (2005) stated that, "the process genre approach helps students to learn the relationship between purpose and form for a particular genre by using some processes of prewriting, drafting, revision, and editing" (p. 20). Those steps can develop students' knowledge about the different of each text type in English and all of composing process. Of course, the process genre approach will give a benefit for students such as the students will know clearly about the process of writing English text.

The process-genre approach has been defined by some experts in the world clearly. According to Babalola \& Latinin (2012), "the process genre approach to the teaching of writing is combination of the process models and the genre theories which came about with the realizations of the limitations of both the process and the genre approaches in developing learners' writing skills" (p. 1). Then, Goa (2007) defines a process genre approach as:

"the term of combination between process models and genre theories in which the concept is not only draws on ideas from genre approaches, such as knowledge of context, the purpose of writing, certain text features, but retains part of process philosophy such as writing skill development and learner response (p. 4)"

Based on both opinions can be inferred that the genre-process approach can develop students' skill in writing, involve students about knowledge of language, and context knowledge.

As an approach of writing, there are some steps that must be followed by the students using the genre-process approach. Yan (2007, pp. 20-22) promoted those stages into six steps;

Preparation. The preparation is the first step in this approach in which teacher begins to prepare the students to write by defining a situation that will require a written text and placing it within a specific genre. The text means are such as narrative, description, 
hortatory exposition, analytical exposition, discussion and other text types. The aim of this activity is to activate the students' schemata and allows students to anticipate the structural features of this genre.

Modeling and Reinforcing. In this second step, firstly, teacher introduces students a model of a genre and the teacher helps the students in understanding the texts, considers the social purpose of the text, including who the audience will be. For example, the purpose of recount text is to reconstruct past experiences by retelling the events according to their actual sequence of events. Secondly, the teacher discusses how the text is structured and how its organization develops to accomplish its purpose, and the students may do some comparisons with other texts to reinforce what they have learned about the particular genre.

Planning. In this third step may teacher can help students in developing an interesting topic for their writing. The topic was developed by making some meaningful activities to activate students' background knowledge. Those activities are brainstorming, mapping, listing, looping, cubing, outlining, or other related activities. For example, showing a picture, asking questions related to the topic.
Joint Constructing. This is the fourth step in the genre-process approach in which teacher and students work together to begin writing a text. While doing so, the teacher uses the writing processes of brainstorming, drafting, and revising. In this step, the students will give contributions information, ideas, and the teacher or the students itself write those information on a text on the whiteboard/blackboard or on computer. The final draft was used by the students as a model to do their individual tasks.

Independent Constructing. At this fifth step students have known and understood of model texts that they are leaning and practice together to construct one or more texts of the same type. Then they have been in the stage of independent writing. In this stage, students will construct their own text based on a predetermined topic with the same type of text they learned on a particular subject. In this stage, the teacher acts as a facilitator to help students who still need their help.

Revising. In this the last step, the draft is constructed by them individually and it will be edited and revised. This does not necessarily mean that teachers have to collect all papers, read, correct, and mark their writings one by one. The students can involve their friends in doing peer editing. Meanwhile, students also can do self editing 
by rereading their draft comprehensively and doing the revision when it is necessary. It aims to make their draft can meet predefined standards.

\section{Why choose a Process-Genre Approach to Teaching Writing?}

The process-genre approach is one of the suitable approaches to teaching writing. This approach has been applied by some English teachers in the world for teaching writing. The result shows that the genreprocess approach has some advantages for teaching writing.

The research finding related to implementation of process-genre approach is Pujianto, Emilia and Ihrom (2014). They found that senior high school students' ability in writing English report text increased by using genre-process approach in term of genre knowledge, writing process, and feedback. The genre knowledge is important to be known by students in writing of English text because every text type has different genre. If they have had genre knowledge they will be easy to construct their text draft correctly. Furthermore, the genre-process approach uses comprehensive writing process. Then, Assagaf (2016) found that the process-genre approach was positive for teaching report text for Arab EFL students.
Another statement about the advantages of using process-genre approach was from Foo (2007) and Agesta \& Cahyono (2017). Foo conducted a research that involved ESL students in a Malaysian secondary school. He used process-genre approach to writing instruction on the expository essays. The result shows that;

"the students who received processgenre oriented writing instruction were able to communicate their ideas in writing more effectively to the reader and developed more relevant ideas to support the purpose of their writing task, compared to the students who received product centered instruction. Instruction in processgenre strategies neither promoted better ability in the way they organized their ideas nor their control of language" (p. 19).

It can be seen that process-genre approach could help students in term of generating and communicating their ideas well. It is caused by the stages of writing process in process-genre approach are organized well. Meanwhile, Agesta and Cahyono employed a research about "the effect of process-genre approach on the Indonesian EFL writing achievement across personality". They found that process genre approach was very effective for Indonesian EFL writing achievement. It can be seen from aspects of writing such as organization, vocabulary, grammar, and mechanism. 
Besides, the advantages than are gotten from the research results. The other advantage is also mentioned by Sari and Saun (2013) that is cited from their article, they are as follow; a) Preparation. It the beginning of the lesson, this stage can help students to know the structural features of a particular genre. b) Modeling and Reinforcing. The teachers give an example of a text to students and the text will discuss together about components of a text. This activity can help students to know the social purpose, the target audience, text structure, and language features. c) Planning. This step can make students to be interested in the topic. It is because students' background knowledge is recalled by teachers. As a result, they can relate their experiences by asking some questions related to the topic discuss. d) Joints Constructing. This step can support students later independent composing because in this step the teachers makes the final draft of the text come from students' contribution. So, the students can develop this draft while they are composing their own text. e) Independent Constructing. Students writing skill can develop through this step because they have an opportunity to write individually presenting their ideas in the written form and apply what have learned. f) Revising. The students can check, discuss, and evaluate their work with their classmates. Meanwhile, the teachers guide their students. As a result, the students' writing skill improves because they can know their mistakes in writing.

\section{The Teaching of Writing}

Writing is one of the four skills that must be taught by teachers at schools. It has been a challenge for teachers. It is caused by "writing is a difficult task for teachers" (Susiyanti \& Yacob, 2016, p. 72). However, the teachers are not allowed to ignore this skill in teaching English language because this skill is the basic skill of language or linguistics intelligence. "Linguistic intelligence refers to the ability to think in words and use the words to communicate one's thought" (Shakouri, Sheiky, \& Teimourtash, 2017, p.32). In addition, writing is also categorized as personal intelligence. Both personal and linguistics intelligence must be developed by teachers.

Therefore, English teachers must have much knowledge about the effective method, approach, or strategies about teaching writing skill. The appropriate method, approach, or strategies can help students easier to master this skill. If teachers do not have them, some obstacles are possibility faced by teachers and students during learning writing skill. Moreover, English teacher also must know the goal of writing, 
for instance writing instruction that will be introduced to the students (Ariyanti, 2016). She also adds that "the teacher should understand that writing includes the activities of practicing, having guidance and also feedback from the teacher" (p. 264).

\section{Text Types (Genre)}

A text is a media for learning a language, especially in learning English in Indonesia. Type of text is commonly called as genre in English. According to Anderson and Anderson (1998), texts are pieces of spoken or written language that have a particular purpose. Meanwhile, Beaugrande and Dressler (1981) defines a text type as "a distinctive configuration of relational dominances obtaining between or among elements of: a) the surface text, b) the textual word, c) stored knowledge patterns, and d) a situation of occurrence" (p.197). The classification of genre in English is influenced by several things, for instances; the author's purpose of writing the text, the function of the text, the language structure (generic structure) used, what language features are used in the text.

English text types are studied as the main material of English subjects for Junior and High Schools. As media for learning English, students will spend much time on discussing the generic structure and language features that are used as material for composing a text. Generic structure and language features are what make the difference in every type of English text available.

Types of text are categorized as monologue, dialogue and functional texts. This article focuses on discussing about monologue texts; they are;

Tabel 1. Types of Texts

\begin{tabular}{|lllll|}
\hline No & $\begin{array}{c}\text { Types of } \\
\text { Texts }\end{array}$ & \multicolumn{1}{c|}{ Aims } & \multicolumn{1}{c|}{$\begin{array}{c}\text { Generic } \\
\text { Structure }\end{array}$} & \multicolumn{1}{c|}{ The Characteristics } \\
\hline $\mathbf{1}$ Narrative & $\begin{array}{l}\text { To entertain the } \\
\text { readers and tell a } \\
\text { story }\end{array}$ & $\begin{array}{l}\text { Orientation, } \\
\text { complication, } \\
\text { resolution, } \\
\text { reorientation }\end{array}$ & $\begin{array}{l}\text { Using past tense, action verb, } \\
\text { the chronology is set }\end{array}$ \\
\hline $\mathbf{2}$ Recount & $\begin{array}{l}\text { Tell something that } \\
\text { has happened in the } \\
\text { past and tell a series } \\
\text { of past events }\end{array}$ & $\begin{array}{l}\text { Orientation, } \\
\text { event(s), } \\
\text { Reorientation }\end{array}$ & $\begin{array}{l}\text { Using past tense, action verb, } \\
\text { adjectives }\end{array}$ \\
& & & \\
& & &
\end{tabular}




\begin{tabular}{|c|c|c|c|c|}
\hline 3 & Descriptive & $\begin{array}{l}\text { To describe someone, } \\
\text { place, or a thing in } \\
\text { detail }\end{array}$ & $\begin{array}{l}\text { Identification and } \\
\text { Description }\end{array}$ & $\begin{array}{l}\text { Using simple present tense, } \\
\text { action verb, adverb, and } \\
\text { special and scientific terms }\end{array}$ \\
\hline 4 & Report & $\begin{array}{l}\text { To present } \\
\text { information about } \\
\text { something }\end{array}$ & $\begin{array}{l}\text { General } \\
\text { classification and } \\
\text { Description }\end{array}$ & $\begin{array}{l}\text { Introducing a group or } \\
\text { common aspects, using } \\
\text { conditional logical connection, } \\
\text { and using simple present tense }\end{array}$ \\
\hline 5 & Explanation & $\begin{array}{l}\text { To explain the } \\
\text { processes involved in } \\
\text { the formation or work } \\
\text { of natural or socio- } \\
\text { cultural phenomena }\end{array}$ & $\begin{array}{l}\text { General statement, } \\
\text { Explanation, and } \\
\text { Closing }\end{array}$ & $\begin{array}{l}\text { Using Simple Present Tense, } \\
\text { action verbs passive voice, } \\
\text { noun phrase, adverbial phrase, } \\
\text { technical terms, general and } \\
\text { abstract noun, conjunction of } \\
\text { time and cause-effect. }\end{array}$ \\
\hline 6 & $\begin{array}{l}\text { Analytical } \\
\text { exposition }\end{array}$ & $\begin{array}{l}\text { To reveal something } \\
\text { to the reader that } \\
\text { something is very } \\
\text { important }\end{array}$ & $\begin{array}{l}\text { Thesis, Arguments, } \\
\text { and Reiteration/ } \\
\text { conclusion }\end{array}$ & $\begin{array}{l}\text { Using modals, action verbs, } \\
\text { thinking verbs, adverbs, the } \\
\text { adjective, technical terms, } \\
\text { general and abstract noun, } \\
\text { connectives / transition }\end{array}$ \\
\hline 7 & $\begin{array}{l}\text { Hortatory } \\
\text { Exposition }\end{array}$ & $\begin{array}{l}\text { To convince the } \\
\text { reader of something } \\
\text { that should or should } \\
\text { not happen or be } \\
\text { done }\end{array}$ & $\begin{array}{l}\text { Thesis, Arguments, } \\
\text { and } \\
\text { Recommendation }\end{array}$ & $\begin{array}{l}\text { Using Simple Present Tense, } \\
\text { modals, action verbs, thinking } \\
\text { verbs, adverbs, the adjective, } \\
\text { technical terms, general and } \\
\text { abstract nouns, and } \\
\text { connectives / transition }\end{array}$ \\
\hline 8 & Procedure & $\begin{array}{l}\text { To help the reader } \\
\text { how to do or make } \\
\text { something }\end{array}$ & $\begin{array}{l}\text { Goal/Aims, } \\
\text { Materials/Equipmen } \\
\text { ts, and } \\
\text { Steps/Methods }\end{array}$ & $\begin{array}{l}\text { Using Simple Present Tense, } \\
\text { Imperatives sentence, adverbs, } \\
\text { and technical terms }\end{array}$ \\
\hline 9 & Discussion & $\begin{array}{l}\text { To present } \\
\text { information or argue } \\
\text { about issues that } \\
\text { develop more on one } \\
\text { side of the problem } \\
\text { ('For Pro and Contra) }\end{array}$ & $\begin{array}{l}\text { Issue, Arguments for } \\
\text { and against, and } \\
\text { Conclusion }\end{array}$ & $\begin{array}{l}\text { Using Simple Present Tense, } \\
\text { use of relating verb / to be, } \\
\text { Using thinking verb, general } \\
\text { and abstract noun, conjunction } \\
\text { / transition, modality, and } \\
\text { adverb of manner }\end{array}$ \\
\hline 10 & Review & $\begin{array}{l}\text { to criticize or } \\
\text { evaluate artwork or } \\
\text { events for the general } \\
\text { public }\end{array}$ & $\begin{array}{l}\text { Orientation, } \\
\text { Evaluation, } \\
\text { Interpretative } \\
\text { Recount, Evaluation, } \\
\text { and Evaluative } \\
\text { Summation }\end{array}$ & $\begin{array}{l}\text { Focus on specific participants, } \\
\text { Using adjectives, long and } \\
\text { complex clauses, and } \\
\text { metaphor }\end{array}$ \\
\hline 11 & Anecdote & $\begin{array}{l}\text { To share with others } \\
\text { an unusual or funny } \\
\text { incident }\end{array}$ & $\begin{array}{l}\text { Generic Structure: } \\
\text { Abstract, } \\
\text { Orientation, Crisis, }\end{array}$ & $\begin{array}{l}\text { Using exclamations, rhetorical } \\
\text { question or intensifiers, } \\
\text { material process, temporal }\end{array}$ \\
\hline
\end{tabular}




\begin{tabular}{|lllll|}
\hline 12 & Spoof & $\begin{array}{l}\text { To tell a story about a } \\
\text { funny event and } \\
\text { entertain the reader }\end{array}$ & $\begin{array}{l}\text { Orientation, Events, } \\
\text { and Twist }\end{array}$ & $\begin{array}{l}\text { Using past tense, adverb, and } \\
\text { the chronology is set }\end{array}$ \\
\hline 13 & News Item & $\begin{array}{l}\text { To inform the reader } \\
\text { of a day's events that } \\
\text { are considered either } \\
\text { newsworthy or } \\
\text { important }\end{array}$ & $\begin{array}{l}\text { Newsworthy events, } \\
\text { Background events, } \\
\text { and Sources }\end{array}$ & $\begin{array}{l}\text { Short, telegraphic information } \\
\text { about story captured in } \\
\text { headline, using action verbs, } \\
\text { using saying verbs, using } \\
\text { adverbs: time, place and } \\
\text { manner. }\end{array}$ \\
& & &
\end{tabular}

\section{CONCLUSION}

Based on the explanation in discussion section, it can be concluded that the process-genre approach is the best approach to teaching writing for English texts at Junior and Senior High Schools in Indonesia. This approach can help the students to understand clearly about the relationship between purpose and form for a particular genre that they can be used in the process of prewriting, drafting, revision, and editing.

All of English teachers in Indonesia are expected to learn and use this approach to teach writing of English texts for their students. This approach is effective because this approach is the combination between process approach and genre approach. In addition, English teachers also expected to use the appropriate and interesting media in teaching writing in order students to be motivated in learning writing.

\section{REFERENCES}

Ariyanti. (2016). The teaching of EFL writing in Indonesia. Dinamika, 16(2), 263-267.

Assagaf, H, T. (2016). A process-genre approach to teaching report writing to Arab EFL computer science students. International Journal of English Linguistics, 6(6), 9-18.

Ahn, H. (2012. Teaching writing skills based on a genre approach to L2 primary school students: An action research. English Language Teaching, 5(2), 216.

Agesta, S., \& Cahyono, B, Y. (2017). Effect of process-genre approach on the Indonesian EFL writing achievement across personality. International Journal of English Language and Linguistics Research, 5(3), 39-48. 
Anderson, M., \& Anderson, K. (1988). Text Types in English 3. ed. South Yarra: MacMillan Education Australia PTYD Ltd.

Babalola, \& Latinin, H. B. (2012). Effect of Process-Genre Based Approach on the Written English Perfomance of Computer Science Students in a Nigerian Polytechnic. Journal of Education and Practice, 3(6), 1-7.

Badger, Richard, \& White, G. (2000). A process-genre approach to teaching writing. ELT Journal, 54(2), pp. 153160.

Beaugrande, R.de., \& Dressler, W, U. (1981). Introduction of Text Linguistics. London: Longman.

Foo, T, C, V. (2007). The effects of the process-genre approach to writing instruction on the expository essays of ESL students in a Malaysian secondary school. A Thesis for Doctor of Philosopy Degree, University of Sains Malysia. Retrieved on May 3th, 2018 from http://eprints.usm.my/9356/1/THE_EF FECTS_OF_THE_PROCESSGENRE_APPROACH_TO_WRITING. $p d f$
Gao, J. (2007). Teaching Writing in Chinese University: Finding an Eclectic Approach. The Asian EFL Journal, $18,1-2$.

Ghufron, M. A. (2016). Process-genre approach, product approach, and students' self-esteem in teaching writing. Indonesian EFL Journal: Journal of ELT, Linguistics, and Literature, 2(1), 37-54.

Gupitasari, H. (2013). The implementation of process-genre approach to teaching writing business letter. Journal of English \& Education, 1(2), 23-30.

Javed, M., Juan, W, X., \& Nazli, S. (2013). A study of students' assessment in writing skills of the English language. International Journal of Instruction, 6(2), 129-144.

Karimnia, A. (2013). Writing research articles in English: Insights from Iranian university teachers of TEFL. Procedia-Social and Behavioral Sciences, 70-901-914.

Khan, I, A. (2016). Utilization of different technologies and media in learning writing skill in English: a case study. European Journal of Education Studies, 2(6), 144-156. 
Kim, Y., \& Kim, J. (2005). Teaching Korean university writing class: Balancing the process and the genre approach. Asian EFL Journal, 68- 89.

Masood, A. \& Farooq, M., U. (2013). Exploiting Authentic Materials for Developing Writing Skills at Secondary Level. Journal of Literature, Languages and Linguistics, 1, 15-25.

Nordin, S, \& Norhisham, M. (2006). The best of two approaches: process-genre approach to teaching writing. The English Teacher, 35, 75-85.

Pujianto,D., Emilia., E., \& I. M. S. (2014). A process of genre approach to teaching writing report text to Senior High School students. Indonesian Journal of Applied Linguistics, 4(1), 99-110.

Purba, R. (2018). Improving the Achievement on writing narrative text through discussion starter story technique. Advances in Language and Literary Studies, ISSN: 2203-4714, 27-30.

Saputra, H., \& Marzulina, L. (2016). Teaching writing by using genre process approach to the eighth grade students of SMP Negeri 22
Palembang. Edukasi: Jurnal Pendidikan dan Pengajaran, 2(1), 112.

Sari, P. P., \& Saun, S. (2013). Teaching writing by using the process-genre approach at Junior Highs Schools. Journal of English Language Teaching, 2(1), 255-264.

Shakouri, N., Sheiky. B. R., \& Teimourtash, M. (2017). On the relationship between linguistics intelligence and recalling lexical items in SLA. International Journal of Research Studies in Education, 6(4), 29-36.

Sibarani, B. (2007). Penerapan Proses Kognitif dan Terapi Cognitive Blocking dalam Peningkatan Kualitas Pembelajaran Menulis. Diksi, 14(2), 78-102.

Suriyanti, S., \& Yacoob, A. (2016). Exploring teacher strategies in teaching descriptive text in Indonesia. Malaysian Journal of Learning and Instruction, 13(2), 71-95.

Tuyen, et. al. (2016). The effects of process genre approach on upper secondary students' writing ability: a case study in a specialized upper secondary school in Vietnam. International 


\section{Journal of English language, literature, and Translation Studies, 3(3), 282-289.}

Wang, P. (2015). Effect of an automated writing evaluation program: students' experiences and perceptions. Electronic Journal of Foreign Language Teaching, 12(1), 79-100.

Yan, G. (2005). A Process genre model for teaching writing. English Teaching Forum, 43(3), 18-26. 